\title{
INTERNATIONAL COLLOQUIUM CLIMATE CHANGE IN MAGELLAN AND ANTARCTIC REGIONS: EVIDENCE AND CHALLENGES FOR THE FUTURE SESSION 3. RESEARCH HIGHLIGHTS FROM THE CHILEAN FJORDS: WATER COLUMN AND SEDIMENTS
}

\author{
INVESTIGACIONES DESTACADAS DE LOS FIORDOS \\ CHILENOS: COLUMNA DE AGUA Y SEDIMENTOS
}

Carina Lange ${ }^{1}$

The Chilean fjords, located between $41^{\circ}$ and $56^{\circ} \mathrm{S}$, cover an area of roughly $241,000 \mathrm{~km}^{2}$ characterized by an extensive coast line composed by a large number of islands, fjords, sounds, basins and gulfs which were formed by glacial erosion during the Quaternary and tectonic sinking of the central Chilean valley. The complex topography limits or controls the exchange of waters between coastal regions and the open ocean, creating micro-environments with oceanographic conditions that sustain unique ecosystems. These are characterized by complex marine-terrestrial-atmospheric interactions that result in high biological production. Strong seasonal climatic changes (e.g. solar radiation, wind, and precipitation) as well as different physical regimens (mixing and/ or stability of the water column) impose an external influence on phytoplankton biomass, primary production, and species composition. Diatoms are the most frequent and abundant group year-round, dinoflagellates are only important on some occasions when they form blooms, and nanoflagellates have the highest abundances in summer and autumn in the most southern area. Thus, high spatial and temporal heterogeneity of phytoplankton assemblages exists.
The fjord region lies mostly under the influence of the main Southern Hemisphere atmospheric circulation pattern, the Southern Westerlies, which in turn, are closely linked to changes within the tropical climate system and climate conditions in coastal Antarctica. High annual rainfall in the fjord region (1,000-7,000 mm year ${ }^{-1}$ and high mean annual river discharges $\left(\sim 2,500-3,500 \mathrm{~m}^{3} \mathrm{~s}^{-1}\right)$ greatly enhance the supply of terrigenous sediment which leaves its mark in the sedimentary record. The river regimen varies with latitude, and three kinds of regimens can be found, i.e. winter-centered pluvial (to the north of $43^{\circ} \mathrm{S}$ ), summer-centered nival (to the south of $47^{\circ}$ $\mathrm{S})$, and mixed pluvial-nival $\left(43^{\circ}-47^{\circ} \mathrm{S}\right)$.

A typical estuarine circulation pattern characterizes the area, determined by an offshore surface flow of freshwater over an onshore flow of oceanic water. The surface freshwater layer separates from the marine layer by a strong pycnocline, resulting in overlapping brackish and marine characteristics in the fjord ecosystem. The productivity of the Chilean fjords is influenced by the combined effect of important contributions of dissolved silicon from freshwater discharge (river runoff and glacial melting) 
as well as the vertical entrainment of Subantarctic Water loaded with macronutrients (nitrate and orthophosphate) from the adjacent oceanic area.

The sediments in the fjord region accumulate at high sedimentation rates (up to $0.8 \mathrm{~cm} \mathrm{yr}^{-1}$, at the sediment surface). The terrigenous organic matter content in the sediments increases from the oceanic area to the heads of the fjords due to local river discharges. Sediments influenced by glaciers have very low organic matter due to dilution by the large amounts of inorganic matter contributed by glaciers. Both freshwater and marine microfossils are abundant in sediment cores, allowing assessment of variability in freshwater input through time which in turn is tied to precipitation on land and river runoff into the fjords.

Most of the oceanographic information for the Chilean fjords and channels (from Puerto Montt at $42^{\circ} \mathrm{S}$ to Cape Horn at $56^{\circ} \mathrm{S}$ ) comes from the CIMAR Program (Cruceros de Investigación Marina en Áreas Remotas; Marine Research Cruises in Remote Areas). This is an ongoing program of the Comité Oceanográfico Nacional (CONA; National Oceanographic Committee) which started with its first cruise in 1995. In all CIMAR cruises, the water column and the surface sediments were sampled intensively, and in some occasions sediment cores were also collected. This yielded a large database on the physical (temperature, salinity, light penetration, currents, tides), chemical (dissolved oxygen, nutrients), and biological (phytoplankton, chlorophyll-a, zooplankton, red tides) characteristics of the water column, and characterization of the sediments in terms grain size, porosity, carbon, nitrogen, trace metals, stable and radioactive isotopes, and organic components. In the past six years several international cruises have taken place in the Chilean fjords and adjacent oceanic area, aimed at the recovery of high-resolution long sediment cores that encompass the time period since the Last Glacial Maximum: JAMSTEC Beagle expedition 2003; Palmer cruise NBP0505 2005; PACHIDERME cruise 2007; and Mirai MR08-06 leg 2 in 2009 which also included present-day observations of water column chemistry and biology, and pelagic-benthic coupling.

In this talk I will present data from ongoing research in the Chilean fjords and adjacent oceanic area, including the water column and the sediments. Some of the themes I will address include: 1) Sea- sonal changes in marine primary production; 2) Fjords as sinks of $\mathrm{CO}_{2}$; 3) Recent shifts in spawning areas of southern hake and anchovy; 4) Fluctuations (present and past) in temperature, precipitation and river discharges into the Inner Sea of Chiloé and Northern Patagonia fjord system, and their impact on biological productivity and phytoplankton species composition; 5) Temperature evolution from highresolution marine sediment cores from Southern Patagonia and the Strait of Magellan; and 6) Holocene storm track record from Lake Tamar.

\section{Challenges}

Intense use of the area began in the 1980s with activities related to aquaculture, fisheries, tourism, and human settlements. Aquaculture is one of the activities that has experienced largest growth and development in the last decade, especially in Regions $\mathrm{X}$ (De los Lagos, $39^{\circ} 15^{\prime}-44^{\circ} 04^{\prime} \mathrm{S}$ ) and XI (Aysén, $43^{\circ} 38^{\prime}-49^{\circ} 16^{\prime}$ S). Salmon farming is one of the most important export commodities of the country. This activity may generate accumulation of organic matter promoting exhaustion of oxygen, change of natural nutrient cycles, methanogenesis and sulfide production, thus altering the chemical composition of the sediments and the ecological structure of the macrobenthos.

The southern region of the Chilean fjords contains enormous potential, including fresh water reserves of worldwide importance such as the Patagonian Ice Fields: the Northern Patagonian Icefield (NPI, 46-47 $\mathrm{S}$ ), Southern Patagonian Icefield (SPI, $48-52^{\circ} \mathrm{S}$ ), and the Darwin Mountains Icefield in Tierra del Fuego (DMI, 54-55 $\mathrm{S}$ ). These notable volumes of pristine waters are associated with an enormous hydroelectric potential that has become an attractive asset inciting investment by energygenerating companies in the region. Nevertheless, possible environmental damages associated with inappropriate management of the affected ecosystems can result in environmental liabilities incompatible with sustainable development of the region. A suitable understanding of the oceanic and climate conditions and the capacity to forecast these are key elements for strengthening the increasing development of this region. Consequently, the growth projected for aquaculture and the fishing industry (artisanal and industrial) as well as possible interventions related 
to the hydroelectric potential of the Patagonia necessitates studies of the highest scientific/technical level in order to meet the new challenges. In this context, it is vital for science and technology to position themselves with long-term monitoring programs (as the COPAS Sur-Austral program) in crucial areas for these unique ecosystems and, in turn, with potential risks for projections of intensive use by activities such as aquaculture, mining, and energy.

Some problems and threats identified are:

- Ignorance of the fragility, resilience, and load capacity of the ecosystems given anthropogenic pressure and global change

- Ignorance of the relative importance of species, habitat, and priority areas for implementing effective protective plans for the zone's biodiversity

- Limited forecasting of changes in the distribution and abundance of fishing resources

- Limited forecasting of the cyclic patterns and prevailing tendencies in terms of the availability and quality of the hydric resources

- Limited use of relevant scientific information in the decision-making processes of both the public and productive sectors. Poor communication between the generators of information (scientists) and social and/or productive actors

- Ignorance of the zone and its marine ecosystems on the part of the productive sector, resulting in lost opportunities for orderly and sustainable development.

\section{ACKNOWLEDGEMENTS}

To the conveners of the International Colloquium for the invitation. Many colleagues have provided unpublished information: J. L. Iriarte (UACh), R. Torres (CIEP), J. Sepúlveda (MIT), L. Castro, L. Rebolledo, F. Tapia and W. Schneider (UDEC), M. Caniupán and F. Lamy (AWI), R. Kilian (U Trier).

\section{LITERATURE CITADA}

Aracena, C., C.B. Lange, J.L. Iriarte, L. Rebolledo \& S. Pantoja 2011. Latitudinal patterns of export production recorded in surface sediments of the Chilean Patagonian fjords $\left(41-55^{\circ} \mathrm{S}\right)$ as a response to water column productivity. Continental Shelf Research, 31(3-4): 340-355.

Caniupán, A. M, F. Lamy, C. B. Lange, U. Ninnemann, R. Kilian, O. Baeza Urrea, H. W. Arz, C. Aracena, D. Hebbeln, J. Kaiser, C. Kissel, C. Laj, G. Mollenhauer, R. Tiedemann, in review. Millennial-scale surface water changes in the Southeast Pacific off southernmost Chile $\left(53^{\circ} \mathrm{S}\right)$ over the past $\sim 60 \mathrm{kyr}$. In review in Paleoceanography

González, H.E., M.J. Calderón, L. Castro, A. Clément, L.A. Cuevas, G. Danieri, J.L. Iriarte, L. Lizárraga, R. Martínez, E. Menschel, N. Silva, C. Carrasco, C. Valenzuela, C.A. Vargas, \& C. Molinet 2010. Primary production and its fate in the pelagic food web of the Reloncaví Fjord and plankton dynamics of the Interior Sea of Chiloé, Northern Patagonia, Chile. Marine Ecology Progress Series, 402: 13-30. Iriarte, J.L., H.E. González, K.K. Liu, C. Rivas \& C. Valenzuela 2007. Spatial and temporal variability of chlorophyll and primary productivity in surface waters of southern Chile $\left(41.5-43^{\circ} \mathrm{S}\right)$. Estuarine, Coastal and Shelf Science, 74: 471-480.

Rebolledo, L., J. Sepúlveda, C.B. Lange, S. Pantoja, S. Bertrand, K. Hughen \& D. Figueroa 2008. Late Holocene marine productivity changes in Northern Patagonia-Chile inferred from a multi-proxy analysis of Jacaf channel sediments. Estuarine, Coastal and Shelf Science, 80:314-322

Sepúlveda, J., S. Pantoja, K.A. Hughen, S. Bertrand, D. Figueroa, T. León, N.J. Drenzek \& C. Lange 2009. Late Holocene sea-surface temperature and precipitation variability in northern Patagonia, Chile (Jacaf Fjord, $\left.44^{\circ} \mathrm{S}\right)$. Quaternary Research, 72(3): 400-409.

COPAS Sur-Austral: Oceanographic Applications for the Sustainable Economic Development of the Southern Region of Chile, CONICYT Programa de Financiamiento Basal para Centros Científicos y Tecnológicos de Excelencia. 
